\title{
Promoting Hospitality and Tourism through Library and Information Services in the $21^{\text {st }}$ Century
}

\author{
Adeniji Paulina Olufunke1, Adeniran Pauline Oghenekaro² \\ ${ }^{1}$ Department of Tourism Studies, Redeemer's University, Ede, Osun State, Nigeria \\ ${ }^{2}$ Tekena Tamuno Library, Redeemer's University, Ede, Osun State, Nigeria \\ Email: adenijio@run.edu.ng, adeniranp@run.edu.ng
}

How to cite this paper: Olufunke, A. P., \& Oghenekaro, A. P. (2020). Promoting Hospitality and Tourism through Library and Information Services in the $21^{\text {st }}$ Century. Journal of Service Science and Management, 13, 702-708.

https://doi.org/10.4236/jssm.2020.134044

Received: July 20, 2020

Accepted: August 25, 2020

Published: August 28, 2020

Copyright $\odot 2020$ by author(s) and Scientific Research Publishing Inc. This work is licensed under the Creative Commons Attribution International License (CC BY 4.0).

http://creativecommons.org/licenses/by/4.0/

\begin{abstract}
This paper focused on the promotion of hospitality and tourism activities through the provision of library services. Information is a valuable resource for enterprises and people alike because they rely on correct information to perform daily activities. Libraries act as gateway or access point to information, concepts, and works of creativity. Services in libraries and information centres play an important role in the advancement of hospitality and tourism businesses. The paper focuses on essential library and information services to promote hospitality and tourism businesses. These library and information services include: making available resources such as maps, directories, bibliographies, biographies, referral services to mention but few. The services highlighted are aimed to promote hospitality and tourism activities in the $21^{\text {st }}$ century.
\end{abstract}

\section{Keywords}

Hospitality, Tourism, Libraries, Information Service, Information Use

\section{Introduction}

The terms hospitality and tourism are grouped as a single industry. Zeglen (2018), defined hospitality as a connection or a mutual relationship that exists between a guest and a host. The guest is received with a friendly attitude and entertained by the host. According to Zeglen, hospitality exceeds protecting and accommodating strangers. It is all about satisfying the guest and providing proper customer service. Some see hospitality as "the activities of helping people to feel welcome and to enjoy themselves" (Richard, Stephen, Anastasia, Anita, \& Gary, 
2015). The hospitality business is all about the provision of accommodation, food, beverage, etc. Slattery (2002) sees hospitality as a matter of protection and survival, which is more associated with etiquette and entertainment. Hospitality tourism business focuses on the provision of accommodation and similar services to people (Anyanwu et al., 2010). Bunja (2003) observes that hospitality is an economic venture which organizes, provides and meets the needs of guests for overnight stays, and enjoys suitable accommodation, food and drinks or beverages.

In recent years, the hospitality and tourism industry has been making a significant contribution to national development. Kale (2018), reported that the tourism sector accounted for 34 percent of Nigeria's GDP and 20 percent of the country's employment creation in 2017. The further report had it that the art, entertainment and recreation, trade, transport, accommodation and food services, administrative, support and other services account for 34 percent of GDP and about 20 percent of employment. The industry is fast-growing and becoming more competitive. It employs both skilled and semi-skilled and under-skilled labour. Human, material and cash are a critical aspect of any organization for achieving desired goals. Without the support of human resources; however, the business will not be able to reach its goal. Good income, increase leisure, and enhanced mobility encourages people to go into hospitality and tourism ventures. Also, in modern times, transportation and accommodation systems have significantly improved coupled with the growth of inclusive tours and other forms of relatively cheap vacation travels leading to a rise in the intention to travel for leisure and pleasure. Tourism is now being embraced by a large and growing number of people rather than few.

Bureau of Labor Statistics (2018), emphasized that hospitality is a service-based sector that carries our leisure activities and provides accommodations to a large number of clients. The hospitality business comprises of companies in charge of food service, accommodations, recreation and entertainment.

The hospitality industry operates in the areas of entertainment such as clubs, bars, and lodging Which takes the form of public houses, resorts, inn, compounds, hotels, hostels, serviced apartments, and motels. According to Munindra (n.d.), the hospitality business includes commercial tourism activities such as airline cabin staff and trained agents. Tourism is social and cultural activities that involve the movement of people to countries or places outside their usual based for personal, business or professional reasons. Sharpley (2014) stated that tourism is; basically, a social activity defined by the occasion of the movement of people to and their temporary stay at a place away from their regular residence.

A library is an institution that provides information resources and services to users. Services provided by libraries aim to meet specific purposes at any given time. Issa (2009) submitted that libraries provide information in all spheres of human development. According to Achitabwino (2007), information and availability of a conducive environment for its free flow is an essential tool in all forms of human life. For national development, relevant and updated information is imperative. Libraries are saddled with the responsibility to provide, manage, and 
disseminate such information in society. They are known to play multiple roles in the form of operations and services to support the teaching, learning, research and community services of the higher institutions of learning where they are established.

Libraries play an essential role in society. They have a long-standing history as the primary providers of recorded knowledge and historical records in nations. They collect, organize (cataloguing, classifying and describing them) and preserve the knowledge in books and other information carriers. Libraries make the knowledge of the past and present available for future reference (Reding, 2005). According to Paul Tiyambe Zeleza's article "The dynamics of book and library development in Anglophone Africa" books and libraries are repositories of knowledge and information gathered over time so for people to access. Information enables individuals to make informed decisions capable of promoting a nation.

Achitabwino (2007) stressed that libraries promote the hospitality and tourism sector by providing them with relevant information. Libraries as custodian of information can be relied on by tourists seeking information on hotels, motels, national parks, mountains and other tourist places. Ekwelem et al. (2011) affirmed that libraries, museums and archives have a variety of collections they make available to users.

\section{Library and Information Services for Hospitality and Tourism}

Libraries are a collection of information resources and services to satisfy users information needs. Libraries are primarily established to acquire, organize, store and make accessible to the users, quickly and seamlessly all forms of information resources they provide. Ranganathan, an Indian librarian and scientist, postulated the five laws of librarianship, stating that:

1) Books are for use;

2) Every user his book;

3) Every book its user;

4) Do not waste the time of the library user; and

5) The library is a growing organism.

These laws commit libraries and librarians to perform their sole duties to ensure that users' information needs are met. The human and material resources in libraries are maintained for the purpose of providing services to users. Indeed, the modern library anticipates the expectations of its users and positively provides support and services to fulfil them. Libraries are tailored to achieve this through different services it renders to their communities (Adeyoyin, 2011). The basic principle of the libraries is that their services are available to all and not restricted to some set of people in the community. Libraries also provide services to the minority groups who for some reason, cannot visit the library physically. The library establishes ways of making library materials and services accessible to its users. Funding of libraries, provision of services, and all that take place in libraries are planned with the idea to create access to what they possess. 
Libraries are the main public institutes that guarantee access to information despite other organizations, based on which they are supported by information community. They perform information literacy service through their reference and information literacy sections. By this, they intervene in tourism services and training information literacy in different ways. For example, libraries have some informing role whereby they support the information needs of specific groups such as tourists (Seifi \& Kazemi, 2019). Libraries possess many devices to attract the hospitality and tourism industry. The author further note that libraries could acquaint the industry with the cultural and historical heritage of a region by presenting various resources such as maps, posters, musical instruments, etc., which in itself would lead to the promotion of cultural and historical identity of a nation. Libraries have an essential role to play a role in hospitality and tourism because they provide cultural and historical information of places.

The role of libraries in the promotion of hospitality and tourism has rapidly increased in the last several years because the industry more and more gathers a lot of information on a destination before deciding to visit it (Violeta \& Sanja, 2010). Tourists seek out information on what their visiting location can offer. Having the right information about a site is an excellent way of enjoying a tourist centre. Public libraries render free city tours service to allow tourists to learn exciting things about the city and its surroundings. Public libraries provide free services to the general public to meet their information needs without a charge because they are being funded by the government and are opened to all in societies. Some libraries provide a Wi-Fi connection to tourists free of charge as shown in Figure 1. This will help them to send and receive emails, download a map or work on social media. Libraries provide comfortable sit, atmosphere to relax and books and arts to tourists (see Figure 2). As a result of information technologies in libraries today, some provide movies and music on various platforms to tourists amongst others as shown in Figure 3. Libraries play an important role in the communities they serve.

The hospitality and tourism sector is concerned with services geared towards leisure and customer satisfaction. Libraries offer services to tourists, as well as those who desire to enjoy their free time. A lot of information resources are available in libraries that provide information relating to leisure and customer satisfaction.

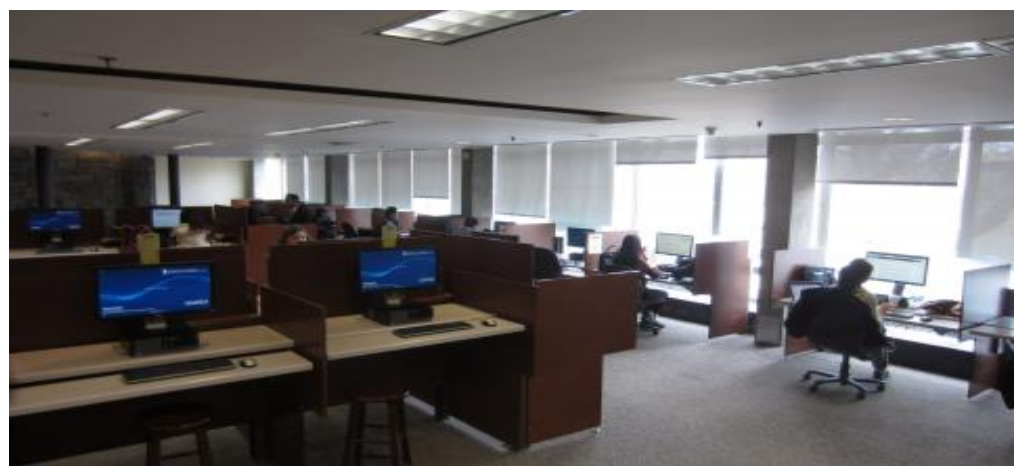

Figure 1. Computer and Wi-fi service. 


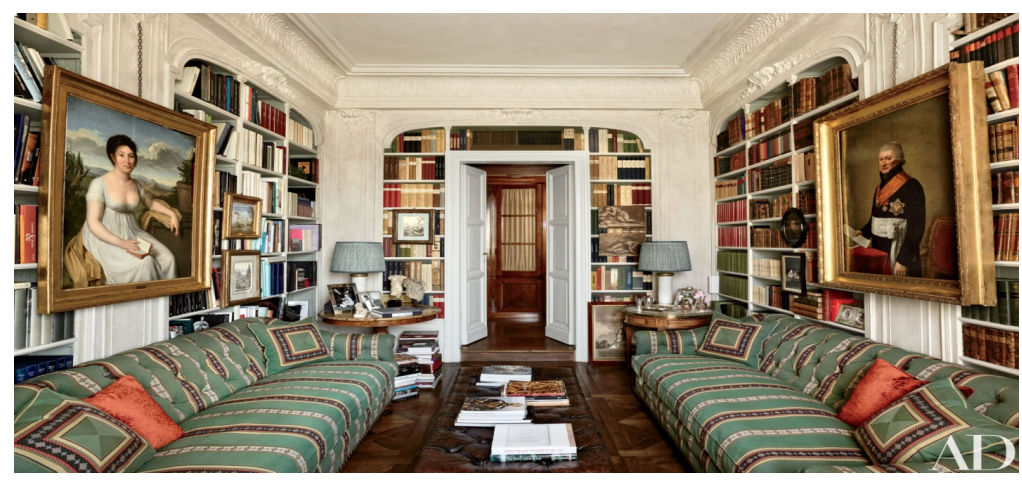

Figure 2. Comfortable space for tourists.

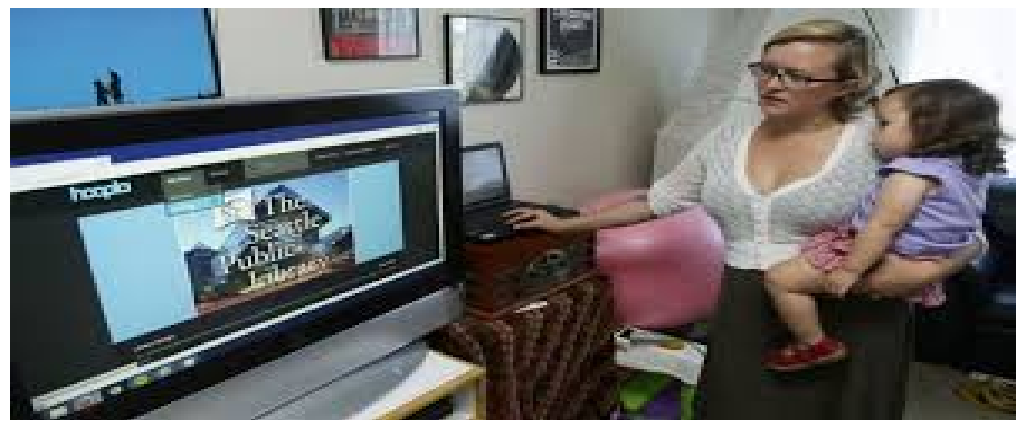

Figure 3. Streaming movies and music.

To maintain and develop their competitiveness due to the rivalry in today business world, the hospitality and tourism enterprise depends on libraries and librarians to furnish them with current information in their field. As argued by Law, Leung, and Buhalis (2009), the promotion of an enterprise, to a great extent, depends on its capability to possess and use accurate information to aid its management and promotion processes. Libraries and information services play a vital role in the promotion of hospitality and tourism businesses. Specific library information services to meet hospitality and tourism needs include:

- Provision of handbooks, atlas, Art designs, maps, bibliographies, directories, biographies, games, recreational facilities, toys, and reference services.

- Provides materials on hospitality with a focus on hotel and food service management.

- Internet Services: Internet provision to tourists who may need to consult e-books, e-journals, courseware, patents amongst others.

- Special facilities materials for those with physical disabilities, e.g., deaf and visually impaired people.

- provide services and media of their native culture for travellers and new citizens to help them find their way in a strange society.

- Information services: libraries offer a vast amount of information within reach of all those with access to electronic media.

- Provides access to information to all.

- Collects information about the local community and makes it readily accessible, often in co-operation with other organizations. 
- Guides users to the appropriate information sources.

- Loan of books and other media: provision of books and other materials for use in the library.

- Provides information services using print and electronic media.

- Provides readers' advisory services including reservation services.

- Performs community information services.

\section{Conclusion}

The paper highlighted the critical role library and information services play in promoting hospitality and tourism industries. It is shown from the discussion that library services for the hospitality and tourism industry are crucial to the development of the sector in a considerable measure. Libraries have played and will continue to play an essential role in promoting hospitality and tourism activities. Library services are imperative especially now that the hospitality and tourism industry is experiencing increasing growth, the world over. Development of libraries should, therefore, be given a priority by the various levels of government. This will help in no small measure to equip libraries and put them in the position to provide more information services in society.

\section{Conflicts of Interest}

The authors declare no conflicts of interest regarding the publication of this paper.

\section{References}

Achitabwino, P. (2007). Libraries and National Development. http://pachitabwino.blospot.com

Adeyoyin, S. O. (2011). Library and Information Resources Management: The Beginners' Text (pp. 1-194). Washinton DC: Eagle Publishers.

Anyanwu, D. E., Adebayo, N. I., \& Nwachukwu, B. C. (2010). Introduction to Tourism Management. Auchi: Allwell Publishers.

Bunja, D. (2003). Organization Business in Hospitality and Tourism, Zagreb, School Book (pp. 50-51). Geneva: Lamlaim Printing Press.

Ekwelem, V. O., Okafor, V. N., \& Ukwoma, S. C. (2011). Preservation of Cultural Hetritage: The Strategic Role of the Library and Information Science Professionals in South East Nigeria. Library Philosophy and Practice, 562.

http://digitalcommons.unl.edu/libphilprac/562

Issa, A. O. (2009). Fundamentals of Library and Information Science. Ilorin: Ilorin Publisher.

Kale, Y. (2018). Tourism Accounts for 34\% of Nigeria's GDP. National Bureau of Statistics. https://shipsandports.com.ng/nbs-tourism-accounts-for-34-of-nigerias-gdp

Law, R., Leung, R., \& Buhalis, D. (2009). Information Technology Applications in Hospitality and Tourism: A Review of Publications from 2005 to 2007. Journal of Travel and Tourism Marketing, 26, 599-623. https://doi.org/10.1080/10548400903163160

Munindra, S. (n.d.). Hospitality Industry and Effects of Globalization. International Research Journal of Management Sociology \& Humanities, 4, 658-662. 
Reding, V. (2005). The Role of Libraries in the Information Society. In CENL Conference Luxembourg (pp. 1-10). Luxembourg.

Richard, P., Stephen, S., Anastasia, C., Anita, W., \& Gary, W. (2015). Fundamentals Business.

https://otn.pressbooks.pub/fundamentalsofbusiness/chapter/chapter-16-hospitality-tou $\underline{\text { rism }}$

Seifi, L., \& Kazemi, R. (2019). The Role of Iran Public Libraries in Development and Promoting of Tourism Services. Library Philosophy and Practice, 2953. https://digitalcommons.unl.edu/libphilprac/2953

Sharpley, R. (2014). Host Perceptions of Tourism: A Review of the Research. Tourism Management, 42, 37-49. https://doi.org/10.1016/j.tourman.2013.10.007

Slattery, P. (2002). Finding the Hospitality Industry. Journal of Hospitality, Leisure, Sport and Tourism Education, 1, 19-28.

U.S. Bureau of Labor Statistics (2018). About the Leisure and Hospitality Supersector. https://www.bls.gov/iag/tgs/iag70.htm

Tosic, V., \& Lazarevic, S. (2010). The Role of Libraries in the Development of Cultural Tourism with Special Emphasis to the Bibliotheca Alexandrina in Egypt. UTMS Journal of Economics, 1, 107-114.

Zeglen, P. (2018). Typology of Tourists and Their Satisfaction Level. https://www.researchgate.net/publication/300109727 TYPOLOGY OF TOURISTS A ND THEIR SATISFACTION LEVEL/stats 